\title{
Optimization of crop-machine parameter on the performance of Kodo pearler
}

DEWENDRA KUMAR, R.K. NAIK, P.K. NISHAD AND P.R. SAHU

Received : 18.07 .2017 ; Revised : 27.08.2017; Accepted : 13.09 .2017

See end of the Paper for authors' affiliation

Correspondence to :

\section{DEWENDRA KUMAR}

Department of Agricultural Processing and Food

Engineering, S.V. College of Agricultural Engineering and Technology and Research Station, Indira Gandhi Krishi Vishwavidyalaya, RAIPUR (C.G.) INDIA

Email : er.dewendra24@gmail. com
- ABSTRACT : Kodo millet (Paspalum scrobiculatum $\mathrm{L}$ ) is a stable food of some tribal's of India especially in the states of Chhattisgarh and Madhya Pradesh. Traditionally, de-husking was done by hand pounding using stone mortar and wooden pestle with metal ring on the tip or by the use of Kodo pearler. The performance was optimize and evaluated at different treatments of Kodo grins and cylinder speeds with factorial SPD. It was observed that cylinder speed and treatment have a significant effect on the performance indices. The results show that the milling recovery and capacity of machine increased as the cylinder speed increase. The milling recovery and capacity of machine was highest $(62.62 \%)$ and $\left(17.65 \mathrm{~kg}-\mathrm{h}^{-1}\right)$ for $24 \mathrm{~h}$ soaked grins at $22.83 \mathrm{~m}-\mathrm{s}^{-1}$ cylinder speed. The head rice per cent was found to be highest $(93 \%)$ for $24 \mathrm{~h}$ soaked grins at cylinder speed $11.57 \mathrm{~m}^{-1} \mathrm{~s}^{-1}$. The percentage of broken rice decreased with the increase soaking time and decrease cylinder speed.

- KEY WORDS : Kodo pearler, Optimization, Treatments, Cylinder speed, Milling recovery

- HOW TO CITE THIS PAPER : Kumar, Dewendra, Naik, R.K., Nishad, P.K. and Sahu, P.R. (2017). Optimization of crop-machine parameter on the performance of Kodo pearler. Internat. J. Agric. Engg., 10(2) : 545-549, DOI: 10.15740/HAS/IJAE/10.2/545-549. 